\title{
The Analysis of Students' Mathematical Literacy Based on Mathematical Ability
}

\author{
Aulia Nurutami, Riyadi, Sri Subanti \\ Pascasarjana Pendidikan Matematika, Universitas Sebelas Maret, Surakarta 57126, Indonesia \\ amy.elnino@gmail.com, riyadifkipuns@gmail.com,sri_subanti@yahoo.co.id
}

\begin{abstract}
One of the 21st century skills is the mathematical literacy ability. The aim of this research was to describe the mathematical literacy ability student based on mathematical ability. This was qualitative descriptive research. The subjects of this research were three 8th grade students an Islamic secondary school at Yogyakarta. The data collection was by test and interview methods. The research instruments was mathematical literacy test used 4 PISA questions and semi-structured interview guidelines. To determine students' mathematical literacy based on students mathematical ability, first step is grouping the students mathematical ability. There are 3 type of mathematical ability, high, average, and low mathematical ability. One subject from every group were chosen namely S1 (students with high mathematical ability), S2 (students with average mathematical ability), and S3 (students with low mathematical ability). Mathematical literacy test and interview were given and analyzed. The analysis result showed that students with high mathematical ability can reach level 2 and level 4 mathematical literacy PISA, students with average mathematical ability can reach level 2 Mathematical Literacy PISA, and students with low mathematical ability can't reach mathematical literacy level 2, 3 or level 4 PISA.
\end{abstract}

Keywords-Mathematical ability; mathematical literacy; $21^{\text {st }}$ century skills.

\section{INTRODUCTION}

As one of the valuable learning subjects, Mathematics should be taught in the world of education in Indonesia due to its nature as a science that exists in every aspect of human life. In real life, mathematics is used to solve various daily faced problems. The subject of Mathematics needs to be taught to equip one with a logical and creative thinking ability, as well as the ability to work collaboratively in a team.

One of the 21 st century skills is the literacy ability. Based on the National Council of Teachers Of Mathematics (NCTM), there are five competencies in mathematics learning: mathematical problem solving, mathematical communication, mathematical reasoning, mathematical connections, and mathematical representation. The capability that includes these five competencies is known as mathematical literacy ability[1].

Mathematical literacy is defined as the ability of a person to formulate, apply and interpret mathematics in various contexts, including the ability to do mathematical reasoning and use concepts, procedures, and facts to describe, explain or estimate phenomena/events [2]. Mathematics literacy as the knowledge to know and apply the basic mathematics in our daily lives [3]. According to Stacey, mathematics literacy as a student's ability to identify and understand the role of mathematics in real life. Mathematics literacy is an issue in society that should be able to access quality public education for mathematical thinking [4].

The Program for International Student Assessment (PISA) is an International Student Assessment program organized by the Organization for Economic Cooperation and Development (OECD) or an organization for economic and development cooperation. PISA aims to monitor the results of educational systems related to the ability of 15-year-olds in reading literacy, mathematical literacy, and literacy science [5]. In addition, PISA also aims to assess the extent to which students near the end of compulsory education have acquired the knowledge and skills necessary to participate fully in modern society. Assessments in PISA not only ensure whether students can reproduce knowledge, but also test how well students can extrapolate from what they have learned and apply that knowledge in unfamiliar settings, both inside and outside school [2]

The Ministry of Education and Culture released the achievement of PISA value on Tuesday, December 6, 2016, in Jakarta [6]. The results of the 2015 survey released showed a significant increase in educational attainment in Indonesia by 22.1 points. Based on the average value, an increase in the value of PISA Indonesia in the three competences tested. In the mathematics competence increased from 375 points in 2012 to 386 points in 2015. The increase raised the position of Indonesia 6 ranks upward compared to the second rank position from below in 2012. The table 1 show of average scores and ranking of student's mathematical literacy ability Indonesia on PISA 2000-2015 [2]:

TABLE I: AVERAGE SCORES AND LITERACY MATHEMATICS RANKING RATINGS OF INDONESIAN STUDENTS ON PISA 2000-2015

\begin{tabular}{|l|l|l|l|l|}
\hline Year & $\begin{array}{c}\text { Indonesia } \\
\text { Average } \\
\text { Score }\end{array}$ & $\begin{array}{c}\text { International } \\
\text { Average } \\
\text { Score }\end{array}$ & $\begin{array}{c}\text { Indonesia } \\
\text { Rank }\end{array}$ & $\begin{array}{c}\text { Total of } \\
\text { Countries } \\
\text { Members }\end{array}$ \\
\hline 2000 & 367 & 500 & 39 & 41 \\
\hline 2003 & 360 & 500 & 38 & 40 \\
\hline 2006 & 391 & 498 & 50 & 57 \\
\hline 2009 & 371 & 496 & 61 & 65 \\
\hline 2012 & 375 & 494 & 64 & 65 \\
\hline 2015 & 386 & 500 & 63 & 69 \\
\hline
\end{tabular}

Based on PISA, the students level of mathematical literacy skills consists of 6 levels as shown in Table 2 [2]. 
TABLE II: THE SIX LEVELS OF MATHEMATICS PROFICIENCY IN PISA 2015

\begin{tabular}{|c|c|}
\hline Level & Characteristics of Tasks \\
\hline 1 & $\begin{array}{l}\text { Students could answer questions involving familiar contexts where } \\
\text { all relevant information was present and the questions were clearly } \\
\text { defined. They were able to identify information and to carry out } \\
\text { routine procedures according to direct instructions in explicit } \\
\text { situations. They could perform actions that were obvious and follow } \\
\text { immediately from the given stimuli. }\end{array}$ \\
\hline 2 & $\begin{array}{l}\text { Students can interpret and recognize situations in contexts that } \\
\text { require no more than direct inference. They can extract relevant } \\
\text { information from a single source and make use of a single } \\
\text { eepresentational mode. Students at this level can employ basic } \\
\text { algorithms, formulas, procedures or conventions to solve problems } \\
\text { involving whole numbers. They are capable of making literal } \\
\text { interpretations of the results. }\end{array}$ \\
\hline 3 & $\begin{array}{l}\text { Students can execute clearly described procedures, including those } \\
\text { that require sequential decisions. Their interpretations are sufficiently } \\
\text { sound to be a base for building a simple model or for selecting and } \\
\text { applying simple problem-solving strategies. Students at this level can } \\
\text { interpret and use representations based on different information } \\
\text { sources and reason directly from them. They typically show some } \\
\text { ability to handle percentages, fractions and decimal numbers, and to } \\
\text { work with proportional relationships. Their solutions reflect that they } \\
\text { have engaged in basic interpretation and reasoning. }\end{array}$ \\
\hline Level & Characteristics of Tasks \\
\hline 4 & $\begin{array}{l}\text { Students can work effectively with explicit models for complex, } \\
\text { concrete situations that may involve constraints or call for making } \\
\text { assumptions. They can select and integrate different representations, } \\
\text { including symbolic, linking them directly to aspects of real-world } \\
\text { situations. Students at this level can utilize their limited range of } \\
\text { skills and can reason with some insight, in straightforward contexts. } \\
\text { They can construct and communicate explanations and arguments } \\
\text { based on their interpretations, arguments and actions. }\end{array}$ \\
\hline 5 & $\begin{array}{l}\text { Students can develop and work with models for complex situations, } \\
\text { identifying constraints and specifying assumptions. They can select, } \\
\text { compare and evaluate appropriate problem-solving strategies for } \\
\text { dealing with complex problems related to these models. Students at } \\
\text { this level can work strategically using broad, well developed } \\
\text { thinking and reasoning skills, appropriate linked representations, } \\
\text { symbolic and formal characterizations, and insight pertaining to } \\
\text { these situations. They begin to reflect on their work and can } \\
\text { formulate and communicate their interpretations and reasoning. }\end{array}$ \\
\hline 6 & $\begin{array}{l}\text { Students can conceptual, generalize and utilize information based on } \\
\text { their investigations and modelling of complex problem situations, } \\
\text { and can use their knowledge in relatively non-standard contexts. } \\
\text { They can link different information sources and representations and } \\
\text { flexibly translate among them. Students at this level are capable of } \\
\text { advanced mathematical thinking and reasoning. These students can } \\
\text { apply this insight and understanding, along with a mastery of } \\
\text { symbolic and formal mathematical operations and relationships, to } \\
\text { develop new approaches and strategies for attacking novel situations. } \\
\text { Students at this level can reflect on their actions, and can formulate } \\
\text { and precisely communicate their actions and reflections regarding } \\
\text { their findings, interpretations, arguments, and the appropriateness of } \\
\text { these to the original situation. }\end{array}$ \\
\hline
\end{tabular}

\section{RESEARCH METHOD}

The research methodology used in this research was descriptive with qualitative approach. Descriptive research is a study intended to collect information about the status of a symptom that exists, namely the state of the symptoms according to what it is at the time of the study [7].

The setting of this research is class VIII MTs Muallimat Muhammadiyah Yogyakarta by the number of 36 students. Subjects in this study were with 3 students with different levels of mathematical ability. The ability of mathematical literacy is grouped according to the average value of daily mathematical test with the value category in table 3 . TABLE III: CATEGORY OF MATHEMATICAL ABILITY LEVEL

\begin{tabular}{|c|c|c|}
\hline No & Score & Level \\
\hline 1 & score $\geq 85$ & High \\
\hline 2 & $70 \leq$ score $<85$ & Average \\
\hline 3 & score $<70$ & Low \\
\hline
\end{tabular}

The data collection method used in this research was test and interview method. The test consists of 4 PISA model problems. Interviews were conducted to find out the achievement of indicator level of student's mathematics lecture not visible on result of literacy test. There are 4 PISA model problem:

The first problem: In 2015, the art performance "KETOPRAK" will be held in a rectangular field with a length of $100 \mathrm{~m}$ and a width of $50 \mathrm{~m}$ prepared for the audience. Tickets are sold out even many audiences stood. How many audiences are there at the art performance? 2,000 audience or 5,000 audience or 20,000 audience or even 50,000 audiences? Give enough explanation for your answers!

The Second Problem: There are 3 towers that have different heights and are composed of two forms namely hexagon and rectangular shapes. How height the shortest tower?

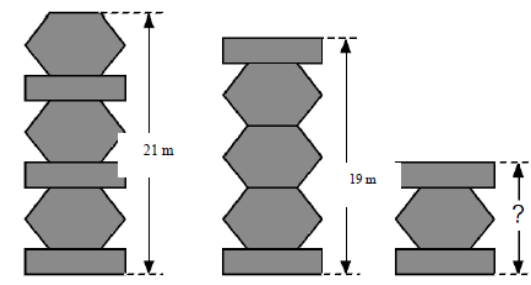

The Third Problem: Souvenir craftsmen will pack 600 pieces of souvenirs into a box in the shape of a cube with a length of $72 \mathrm{~cm}$. The souvenir is also in the form of a cube with a length of $14.4 \mathrm{~cm}$. How many boxes do these craftsmen need so that all their souvenirs can be packed?

The Fourth Problem: The school wants to build a $20 \mathrm{mX} 15 \mathrm{~m}$ hall. On the floor of the hall, brown ceramic tiles will be installed. Therefore, the school must buy ceramics. There are various sizes of ceramics, namely $15 \mathrm{cmX} 15 \mathrm{~cm}$, $20 \mathrm{cmX} 20 \mathrm{~cm}$, and $25 \mathrm{cmX} 25 \mathrm{~cm}$. To buy ceramics, the school must buy ceramics per carton with one box containing 8 pieces of ceramic. According to your opinion, which ceramic size should be purchased by the school so that the remaining ceramics can be as minimal as possible? Give an explanation of your answer!. How many ceramic boxes should the school buy according to the size that you think is the most appropriate? Give an explanation of your answer!

The analysis used in this study was analysis to determine the level of mathematical literacy. Indicator of ability level of mathematics literacy used is Table 1.

\section{RESULTS AND DISCUSSION}

Mathematics literacy test was conducted on Tuesday, January 16, 2018 in grade VIII D with the number of subjects of 3 students representing high mathematical ability students (S1), average mathematical ability students (S2), and low 
mathematical ability students (S3). Meanwhile, the interview was conducted on Thursday, January 18, 2018.

Based on the results of tests and interviews obtained the results of analysis of the three subjects as follows:

\section{A. Students with High Mathematical Ability (S1)}

Based on the results of the analysis of students with high mathematical ability (S1) able to do all the questions given, but the results are not all perfect.

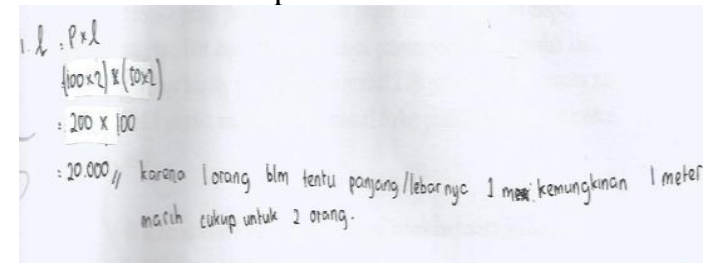

Figure 1. The example of student's S1 answer to the first question

Figure 1 show that $\mathrm{S} 1$ able to answer the problem that can measure the ability of level 2 math literacy correctly. Based on test results and interviews indicate that $\mathrm{S} 1$ almost meets all the indicators of level 2. S1 is able to interpret and recognize situations with contexts that require a direct conclusion. Based on the interview results, S1 was able to sort the relevant information from a single source, and use a single presentation method. Work on basic algorithms, use formulas, execute procedures or agreements. However, S1 has not been able to provide a precise reason for the outcome, it appears in the interview results.

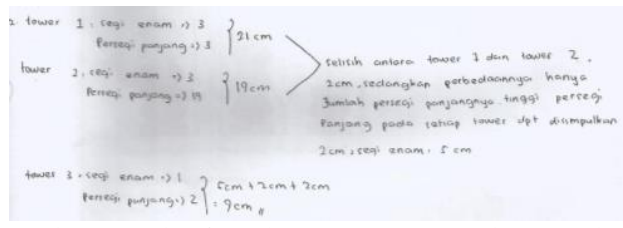

Figure 2. The example of student's S1 answer to the second question Figure 2 show that $\mathrm{S} 1$ is able to answer questions that can measure the ability of level 4 math literacy correctly. Based on test results and interviews indicate that $\mathrm{S} 1$ almost meets all 4 level indicators. S1 is able to work effectively with models in concrete but complex situations that may involve restrictions to make assumptions. Selecting and combining different representations, including symbols, relates them to real situations. Based on the results of the interview, S1 was able to present the reasons with some views in clear context. In addition, $\mathrm{S} 1$ is able to provide explanations and communicate them with arguments based on their interpretations and actions

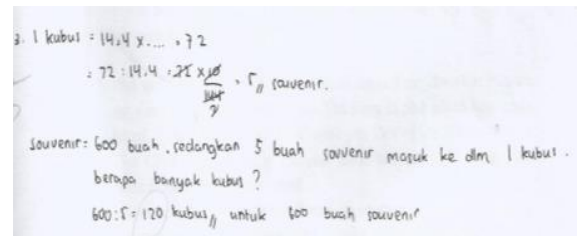

Figure 3. The example of student's S1 answer to the third question

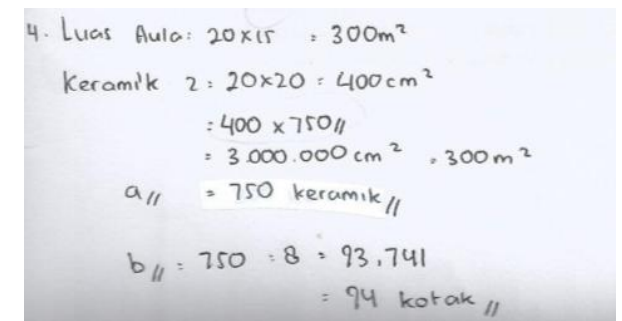

Figure 4. The example of student's S1 answer to the fourth question

Figure 3 and 4 show that for question number 3 and 4 with level 3, S1 has not been able to finish it well. S1 has answered the question but the answer is still wrong, meaning S1 has not been able to perform the procedures clearly, including procedures that require decisions in sequence and have not been able to solve problems, and implement a simple strategy. $\mathrm{S} 1$ has not been able to interpret and use representations based on different sources of information and raise the reasons directly. S1 has not been able to communicate the results of their interpretation. There are some miscalculations and hasty inferences.

\section{B. Students with Average Mathematical Ability (S2)}

Based on the results of the analysis of students with average mathematical ability (S2) is able to do all the questions given, but the results are not all perfect.

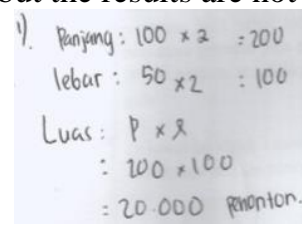

Figure 5. The example of student 's S2 answer to the first question

Figure 5 show that $\mathrm{S} 2$ able to answer the problem that can measure the ability of level 2 math literacy correctly but not perfect. Based on the results of the tests and interviews indicate that $\mathrm{S} 2$ almost meets all level 2 indicators. The $\mathrm{S} 2$ is able to interpret and recognize situations with contexts that require a direct conclusion. Based on the results of the interview, S2 was able to sort the relevant information from a single source, and use a single presentation method. Work on basic algorithms, use formulas, execute procedures or agreements. However, S2 was not able to give a precise reason of the outcome, it appeared in the interview results.

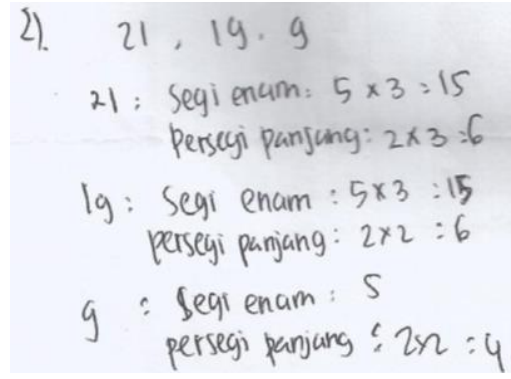

Figure 6. The example of student's S2 answer to the second question 
Figure 6 show that $\mathrm{S} 2$ is able to answer questions that can measure the ability of level 4 math literacy correctly. Based on the results of the tests and interviews, the $\mathrm{S} 2$ almost met all the indicators of level 4. S2 thought that the size of rectangle and the hexagon. S2 is not yet fully able to work effectively with models in concrete but complex situations that may involve restrictions to make assumptions. Selecting and combining different representations, including symbols, relates them to real situations. Based on the results of the interview, S2 has not been able to provide an explanation with a logical argument.

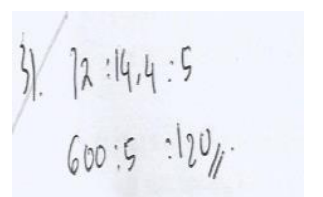

Figure 7. The example of student‘s S2 answer to the third question

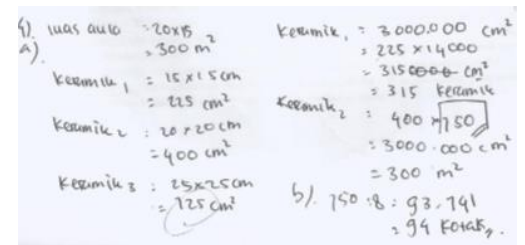

Figure 8. The example of student's S2 answer to the fourth question

Figure 7 and 8 show that for question number 3 and 4 with level 3, S1 could not finish it. S1 could answer the question but still improper. This indicates that $\mathrm{S} 1$ has not been able to perform the procedures clearly, including procedures that require decisions in sequence and have not been able to solve problems, and implement a simple strategy. S1 could not interpret and use representations based on different sources of information and pose its reasons. S1 has not been able to communicate the results of their interpretation. There are some miscalculations and hasty inferences.

\section{Students with Low Mathematical Ability (S3)}

Based on the results of the analysis of students with average mathematical ability (S3), they were able to do all the questions given, but not all the answers are correct.

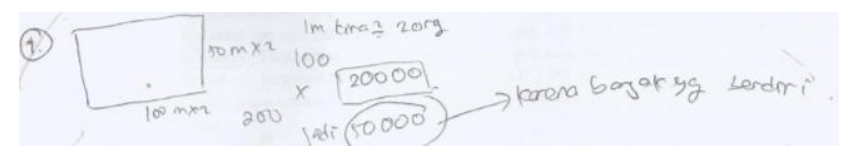

Figure 9. The example of student's S3 answer to the first question

Figure 9 show that $\mathrm{S} 3$ answers questions that can measure the ability of level 2 math literacy but the answer is wrong. Based on the results of the tests and interviews shows that S3 has not met all the indicators of level 2. Based on the results of interviews, S3 has not been able to sort the relevant information from a single source, and using a single presentation. S3 has not been able to work with basic algorithms, using formulas, implementing procedures or agreements. S3 has not been able to give a precise reason of the outcome, it appears in the interview results.

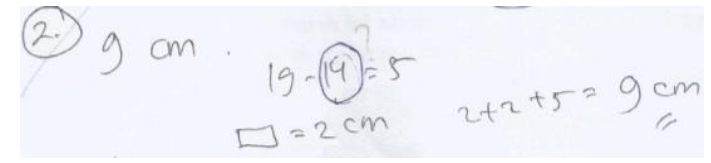

Figure 10. The example of student's S3 answer to the second question

Figure 10 show that $\mathrm{S} 3$ answers questions that can measure the ability of level 4 math literacy but the answer is wrong. Based on the results of tests and interviews show that S3 has not met all level 4 indicators. S3 is still guessing the right size of the rectangular and hexagon. S3 is not yet fully able to work effectively with models in concrete but complex situations that may involve restrictions to make assumptions. Selecting and combining different representations, including symbols, relates them to real situations. There is an error in writing the unit length. Based on the results of interviews, S3 has not been able to provide an explanation with a logical argumentation.

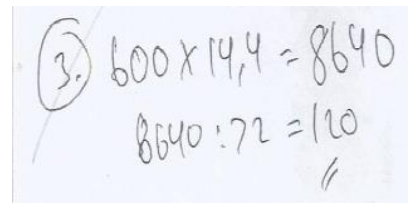

Figure 11. The example of student's S3 answer to the third question

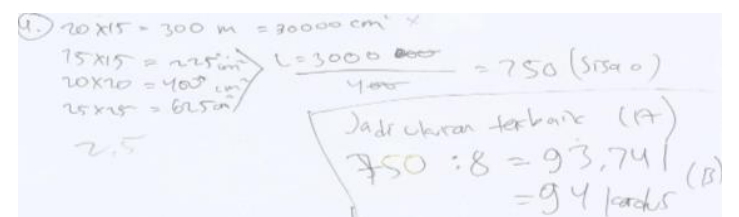

Figure 12. The example of student"s S3 answer to the fourth question

Figure 11 and 12 show that for question number 3 and 4 with level 3, S3 has not been able to finish it well. S3 has answered the question but the answer is still wrong, meaning S3 has not been able to carry out the procedures clearly, including procedures that require consecutive decisions and have not been able to solve problems, and implement a simple strategy. S3 has not been able to interpret and use representations based on different sources of information and express the reasons directly. S3 has not been able to communicate the results of their interpretation. There are some miscalculations and hasty inferences.

Comparison of mathematical literacy between Students with High, Average and Low Mathematical Ability are presented in Table 4. S1 is able to meet level 2 and level 4 indicators, while for level $3 \mathrm{~S} 1$ problem has difficulty to answer the problem correctly. So it can be concluded that S1 is at level 4 math literacy ability. S2 is able to meet some level 2 indicators, while for level 4, S2 still guessing the right answer and for a matter of level 3, S2 has not been able to answer correctly with a logical argumentation. So it is concluded that S2 is at level 2 of mathematical literacy ability. S3 students have not fulfilled any indicators at the level of 2, 3 and 4. So it is concluded that S3 should practice many questions such as PISA type problem. 
Table 4: Comparison of Mathematical Literacy Between Students with High, Average and Low Mathematical Ability

\begin{tabular}{cccc}
\hline Number Test PISA & \multicolumn{3}{c}{ Subject } \\
\cline { 2 - 4 } Problem (Level) & S1 & S2 & S3 \\
\hline 1 (Level 2) & $\checkmark$ & $\checkmark$ & $\mathbf{x}$ \\
2(Level 4) & $\checkmark$ & $\mathbf{x}$ & $\mathbf{x}$ \\
3(Level 3) & $\mathbf{x}$ & $\mathbf{x}$ & $\mathbf{x}$ \\
4(Level 3) & $\mathbf{x}$ & $\mathbf{x}$ & $\mathbf{x}$ \\
\hline
\end{tabular}

\section{CONCLUSION}

Based on the results of the research, each student has a different level of literacy ability. Although not all students meet the indicators given, but in solving the problem some students are able to understand the purpose of the problem and formulate the problems stated in the problem. Some students are also able to solve, interpret problems and present their answers quite well. This is suit with research result that mathematical literacy is a person's ability to formulate, solve, and interpret problems based on the existing context [8]. The results of this research are in line with the results obtained from the research which states that Indonesian students are only able to answer questions PISA level 1, 2, 3, and only some students can solve level 4 [9].

The analysis result showed that students can only answer of 2 question with level 2 and 4 mathematical literacy, whereas in question number 3 and 4 with level 3 mathematical literacy, student can not achieve resolving. Result shows that the ability of students' mathematical literacy suggested that the interview should be done shortly after the completion of the test so that students will not forget their answers, more questions should be given and be well balanced.
Based on the result of research it can be concluded as follows: students with high mathematical ability can reach mathematical literacy level 2 and level 4 PISA. Students with average mathematical abilitycan reach mathematical literacy level 2 PISA. Furthermore, students with low mathematical ability, can not reach mathematical literacy level 2, 3 and level 4 PISA.

\section{REFERENCES}

[1] E. Maryanti, Peningkatan Literasi Matematis Siswa Melalui Pendekatan Metacognitive. Bandung: Universitas Pendidikan Indonesia, 2012.

[2] OECD, PISA 2015 Assessment Framework Key Competencies in Reading, Mathematics and Science. Paris: OECD Publishing, 2015.

[3] B. Ojose, "Mathematics Literacy: Are We Able To Put the mathematics We Learn Into Everyday use?", Journal of Mathematics Education, vol. 4(1) 89-100, 2011.

[4] D. S. Brawley, "College Mathematics Literacy Workers of The Young People's Project Chichago: A Community of Practice, "Journal of Urban Mathematics Education, vol. 5(1), pp. 44-54, 2012.

[5] S. Thomson \& L. D. Bortoli, Exploring Scientific Literacy: How Australia Measures Up The PISA 2006. Australia: Acer Press, 2008.

[6] Kemendikbud, Peringkat dan Capaian PISA Indonesia Mengalami Peningkatan,
(Online), https://www.kemdikbud.go.id/main/blog/2016/12/peringkat-dancapaianpisa-indonesia-mengalami-peningkatan, 2016.

[7] S. Arikunto, Dasar-Dasar Evaluasi Pendidikan. Jakarta: Bumi Aksara, 2012.

[8] K. Stacey, Mathematical an Scientific Literacy Around The World", Journal of Science and Mathematics education in Southeast Asia, vol. 33 (1), pp. 1-16, 2010.

[9] S. I. Edo, et. al., "Investigating Secondary School Students' Difficulties in Modelling Problems PISA-Model Level 5 and 6", JIMS Journal, vol. 4(1), pp. 41-58, 2013. 